are more speedily restored to their normal state than when the powers of the system are left unaided to struggle in subduing the complaint.

Again, the ideas expressed regarding the impropriety of arresting the progress of inflammation in the first instance, and that it is essential that in the skin special actions should be suffered for a time, are at variance with the common understanding and conduct of men, and opposed to the laws which regulate the actions of organised animate bodies. When these natural laws remain undisturbed every part of the machine continues to perform exactly the functions for which it was destined by its maker, but when any barrier arises in opposition to the regulating influence of these laws, the whole machinery, or some part of it, suffers. Now, according to the laws of nature, in correcting the disturbed condition of animated beings, it is universally observed that the less the mischief done the more easily is it remedied, and that the longer the injuring cause continues uncorrected the greater will be the damage in the parts affected, and consequently the more difficult to cure. Thus, we see that Dr. Wilson's views on this subject are untenable, and his practice empirical.

At page 13, near bottom of first column, it is stated, "There is no better test of the physician's professional character than is afforded by his practice in erysipelas. From the rapidity with which its symptoms are developcd most of the treatment in this fever is superfluous, yet much affects to be specific; and thus the boaster triumphs in a cure where the true physician is content with acknowledging a result."

So far as I know the only way to test the superiority of one medical man's practice over that of another in the management of any form of disease, is for each to give a clear and distinct account of a very considerable number of successive cases which had occurred to him during a period of fifteen or twenty years, together with a conscientious detail of the mode of treatment pursued, and the result of that treatment. It is only by proceeding in this manner that any one can decide whether the preference is to be given to the practice of the "true physician" or to the "boaster." Universal consent, will, in all probability, decide in favour of him who, by the use of means, most speedily relieves the sufferer, and ultimately recovers him.

In The Lancet for March 30, 1844 (page 57), last sentence, Dr. Wilson notices a case which came under his care after having been bled; he says, "The bleeding on the first day of the eruption, though against ordinary rule in erysipelas, was practised with a sound discretion; it had been of the greatest use in alleviating the headach, and had probably shortened the duration of the disease." After this admission, I trust the doctor will act accordingly.

\section{PATHOLOGY OF ACUTE RHEUMATISM, AND ON THE \\ PREVENTION OF HEART DISEASE.}

By J. J. Furityall, M.D., London.

Great obscurity envelops the pathology of acute rheumatism, and we know next to nothing of the canses, through the operation of which, during its course, disease is set up in the heart. The difficulties of investigation are increased by the yet infant state of analytic organic or animal chemistry; yet the importance of a successful research, by which functional or organic mischief in the heart may be prevented, need not be pointed out at length, for every one will allow, that while such disease is often highly distressing to the rich, it cannot fail to be calamitons in every respect to the poor. Any attempt, then, however lumble, whether successful or not, to throw light on this sulject, ought to be received with the utmost allowance; my object is merely to place the following opinions before your professional readers, in the hope and in order that the practice recommended below may be tested at the bedside. I do not mean to enter into the whole details of the treatment, but only so far as prevention of heart disease is concerned.
In common with, I presume, every practitioner, I was soon struck with the evidences of an acid diathesis, prevalent throughout the whole system, and visible in the secretions, but more particularly in the perspiration. One gentleman in alluding to this latter fact (Dr. Wigan) thus graphically writes:-" I had often observed that scissors and other articles of steel, and even the fire-irons in the bedroom, were rusted in a short time, as if they had been subjected to the steam of vinegar." Now, as we know the perspiration and urine to be secretions eminently depuratory of the blood, it appears to me that an unusually acid state of these must involve a supposition that the blood itself, instead of being gently alkaline, as in health, has, by disease, undergone a modification, approaching to a reverse condition, and that it is labouring to relieve itself of its morbid load through these secretions. If this be correct, we cannot doubt that such a state of the blood must prove highly morbidly stimulant to the heart and whole arterial system, as well as to their associated nerves; thus we might, at once, account for the general excitement of the arterial system, and, perhaps, for the violent pains which are so marked in acute rheumatism.

Besides this state, it is now believed that there is in this disease a great increase of fibrine in the blood, and the more acute the attack the greater the quantity of fibrine. Andral, in his "Hrmatologie Pathologique," tells us that the quantity of fibrine in healthy blood varies from 2.5 to 4 . in the 1000 parts; but that in articular rheumatism the mean increase fluctuated between 7 and 8 per 1000 , and the maximum increase amounted to 10.2 or more than triple its natural quantity. He writes, "Nous avons examiné le sang, chez 24 individus, atteints de cette maladie, et dans 53 saignées qui leur ont été pratiquées; parmi ces 21 malades, 14 etaient affectés de rheumatisme articulaire aigu et 10 de rheumatisme soit sub-aigu soit chronique. Chez les 14 affectés de rheumatisme articulaire aigu, la fibrine se montra. constamment plus abondante qu'à l'etat normal, tant qu'ils furent saignés pendant la grande intensité des douleurs, et pendant la durée de la fievre. Chez ceux qui furent saignés, après un notable amendement des douleurs, et après la disparition de la fièvre, nous trouvàmes la fibrine diminuée bien que se conservant encore audessus de son type normal. Dans les cas, enfin, où, après un mieux passager, les douleurs reprenaient plus de vivacité, et ramenaient la fièvre, la fibrine montait de nouveau à un chiffre plus elevé." May we not suppose that the increase of fibrine brings back the pains and fever? "Le maximum de fibrine dans nos cas de rheumatisme articulaire aigu a été 10.2; c'est à dire, plus du triple de sa quantité moyenne. Le minimum de fibrine dans ces mêmes cas, alors qu'il y avait encore des douleurs et de la fièvre a été 4.1 ; ce chiffre ne s'est rencontré qu'une seule fois. Enfin, la quantité moyenne de fibrine a oscillé entre 7 ou 8 . L'intensité et l'etendue des douleurs nous ont paru exercer sur l'augmentation du chiffre de la fibrine une influence bien plus puissante que l'epoque de la maladie et que sa durée. Toutes choses egales d'ailleurs, la quantité de fibrine augmente donc avec les douleurs, et la fièvre. Si le rheumatisme est très intense dès son debut on peut dès ce debut trouver dans le sang autant de fibrine qu'on en trouvé seulement plus tard dans les cas où le rheumatisme n'acquiert que peu à peu un grand developpement; ainsi, le troisième jour, nous avons vu la fibrine deja montée à 8 . Si à la suite d'une saignée, le rheumatisme ne s'amende pas, la fibrine, maluré la perte de sang, reste la même ou augmente, et on la voit ainsi echapper à l'influence de la saignée et de la diete tant que les douleurs et la fièvre ne diminuent pas. Ainsi nous avons trouvé le chiffre 10 en fibrine chez un individu qui, parvenu au 13 ème jour de son rheumatisme, avait deja subi trois saignées. Il peut arriver que vers l'epoque mềme de la convalescence, la fibrine bien que devenue moins abondante, se conserve encore en exces, pendant un certain temps, puis elle descend plus ou moins lentement vers son chiffre normal." The dependance of the pains and excitement on the proportion of the fibrine in the blood seem to be pretty clearly pointed out, both increasing and diminishing with the augmentation or diminution of the quantity of fibrine. 
We have, then, two morbid states of the blood in this disorder, which must powerfully tend to excite inflammatory action in the serous membrane of the cardiac ventricles, and of the left ventricle in particular. The subversion of the alkaline state in the blood could not but prove highly exciting to the endocurlium, thus causing hypertrophy and inflammation; while the superabundance of the fibrine tends to favour the formation of deposits within the fine interstices of the cardiac valves and parts adjacent, leading to an embarrassment of their action, until the valves can no longer subserve their natural functions.

In addition to these causes, we know that the chosen site of rheumatic action is the fibrous and fibro-serous textures, and as these textures abound in and about the heart, we have thus another cause powerfully delernining the morbid action of the heart.

From the earliest years of my practice $I$ have tried alkalies in rheumatism, but not in an efficient manner. I found them alwavs of service, bat only as anxiliaries, the general excitement and inflammatory epiphenonena requiring the additional use of other remedies; but since 1830 I have used alkalies more perseveringly than before chiefly the liquor or carbonas potasspe, and I have rot ceased giving them until after the marks of an acid diathesis had disappeared, or that the alkalies disagreed with the stomach, which latter circumstance has rarely happened.

Since that yaar I do not believe that one case of hear disease in acute rheumatism has occurred during treatment in my practice, where the alkaline treatment has been fairly carried out; and I must have, during the time mentioned, treated at least fifty such cases, withou counting any examples of chronic or subacute rheumatism.

Now, as heart disease is said to occur very frequently (it has been said in one out of every three cases), it will be well worth while to try what I recommend, and to substantiate my correctness, or to prove that $\mathbf{I}$ am mistaken in the benefit to be derived from an alkaline treatment; and, as an additional recommendation, the medical man can, and ought, to prescribe other remedies at the same time. During the years mentioned, my practice was carried on in the country, and was of such a nature that if any one fell ill again, who had once been under my treatment, he would lave probably applied to me again, or I should have heard of the recurrence of disease. In proof of this, I may mention that my notes contain the cases of many who have been under my care for the second or third time. It is this circumstance of my having been able to watch the after-progress of my patients that gives weight to my assertion; for, in a metropolitan or a widely-spread practice, relapses or fresh attacks might occur, and yet the practitioner hear nothing of them.

I have alyeady said that I do not solely rely on the alkali, excepting as a prophylactic against heart disease in rheumatism, for although $I$ had heard of a practice, general in some parts of England, of giving alkali, and I had also heard of the success of such treatment, yet $I$ found myself obliged to combine it with other remedies. I do not mean, in the present paper, to go into the detail of the different modes of treatment, nor to describe the indications, pointing to one mode of treatment rather than to another, but I would ask those medical gentlemen who are well placed for such an experiment, to make a persecering trial of adding moderate, yet not too small, doses of the liquor or carbonas potasse, to colchicum, or to any other (not chemically incompatible) remedy which they may be in the habit of prescribing; and I would ask them to watch and report the result, whether in confirmation or refutation of the otiology here propounded. My own conjectures as to the morlus operandi of the alkali are, that it may act in a four-fold way :-

First. As a neutraliser of the acid predominant in the system, and as a restorer of the alkaline condition of the blood.

Second. As a thinner of the fibrine superabounding in the blood; for the physiologist of these days correctly maintains that a gently alkaline condition is essential to the normal fluidity of the blood.

Third. It may act as a sedative, indirectly, by the two first modes of action.

Lastly. It may act as a diuretic, thus helping to carry off the morbid elements of the blood.

Accorling to Andral, and others, blood-letting shows little or no power, either in dininisling the fibrine, or in curing the disease, and cases of acute pheumatism are on record in which heart discase occurrcd, in spite of a treatment very active, and in every respect able, excepting that no alkali had been given. On the other hand, the cases treated by myself, and wherc alkali was pretty freely given, show a marked cxemption from heart disease.

I trust sufficient has been written to indnce a fair trial of a combined alkaline and antiphlogistic treatment in acute rhcumatism. Let theory or hypothesis be laid aside, and the facts alone tested, and if a successful result should lead to the general arloption of a plan of treatment whereby the poor may be saved from the horrors of heart disease, the rich from its discomforts, and all persons from curtailment of life, I should feel myself most happy in having male the foregoing remarks, nor would you be otherwise than pleased at having given them publicity in $y \circ \mathrm{wr}^{2}$ widely-circulated periodical.

Weymouth-street, Portland-place, April 13, 1844 .

THE DUALTTY OF THE MIND.

By JAMEs SHEPPARD, Esq., Stonehouse.

THE question lately brought under the attention of the profession, relating to the duality or non-duality of the mind, by Dr. Wigan, is one demanding our most serious consideration; it is a fundamental question to be considered before we can enter on any theory either of the constitution of the mind, or of insanity, or of the metaphysical relations of the mind with organised matter. Refiection has convinced me that the mind is not, cannot be dual ; that, indeed, the mind is but one entire whole, depending for its perfect development on an entire brain; that a perfect organ is required for the development of a perfect function is a demonstrated truth, though there be many degrees between perfection aud that species of imperfection which we denominate disease. It is not because one hemisphere of the brain presides over the functions of the opposed sides of the body that one hemisphere is capable of developing a perfect mind. If Dr. Wigan is one of those who consider the mind as a secretion from or as emanating from the brain as its cause, that is, if Dr. Wigan maintains (as I fear he must from the position he has assumed) the materiality of the mind, I would not enter into the controversy with him; but, if he simply means that the mind is made up of two minds, to which conclusion he is led by a consideration of the cerebral organisation on the one hand, and of the mental manifestutions on the other, then, considering his position a false one, I am prepared to dispute it with him. I shall not attempt to enter into a metaphysical disquisition on the nature of the inind, as to whether it is simply the sum of the faculties of the soul, or as to whether mind and soul are identical; I shall consider the mind as signifying the whole of the mental manifestation4.

Dr. Wigan sets out by stating that " each cerebrum is a distinet and perfect whole, as an organ of thought." This conclusion he arrives at from the notorious fact that two distinct and opposing wills frequently exist in a sane man at the same moment, and that insane persons often carry on a conversation with themselves, and frequently profess diametrically opposite opinions at the same moment. Such reflections, coupled with the double nature of the cerebral organisation, appear to be the basis of $\mathrm{Dr}$. Wigan's theory of the duality of the mind, a theory which it is much easier to propose than it is either to prove or to disprove; neither by inductive reasoning, nor by tangible proof. does Dr. Wigan support it; his reasoning and his conclusions are, in my opinion, false.

That the brain is a double organ is certain ; that each hemisphere is as distinct in its organisation and in its 